\title{
Facile synthesis of chiral 2-hydroxy acids catalyzed by a stable duck $\varepsilon$-crystallin with endogenous L-lactate dehydrogenase activity
}

\author{
Chi-Yue Wua, Shui-Tein Chen ${ }^{b}$, Shyh-Horng Chiou ${ }^{a, b}$ and Kung-Tsung Wang ${ }^{\mathrm{b}, c}$ \\ "Institule of Bioctemical Sciences, and 'Institute of Biological Chemistry. National Taiwan University, Academia Sinica, Taipei, \\ Taivan and 'Department of Chemistry. National Taiwan University. Taipei, Taiwan
}

Received 13 February 1992; revised version received 9 March 1992

Duck E-crystallin, an abundant structural protein in lenses of some avlan specles, was shown to possess a genuine and stable L-lactate dehydrogenase (L-LDH; EC 1.1.1.27) activity suitable for the application to enzyme technology as a catalyst for the synthesis of chiral $a$-hydroxy acids. Two pharmaceutically important intermediates, 2-hydroxy acids (S)-2-hydroxybutanoic acid (S)-2-hydroxypentanoic acid) have been synthesized in high yields and optical purity utilizing un in situ NADH regeneration system of duck e-crystallin coupled with formate/formate dehydrogenase. This enzyme system is also shown to offer some advantages over the conventional L-LDH sources from several mammalian species.

Lens clystallin; Lactate dehydrogenase; Chiral synthesis; 2-Hydroxybutanoic acid; 2-Hydroxypentanoic acid; Duck

\section{INTRODUCTION}

Bioorganic synthesis based on enzymatic catalysis is providing an increasingly important tool in the methodology of enantio-selective synthesis of valuable organic intermediates (i.e. chiral compounds) [1,2]. Despite many practical applications of enzymes for the generation of chiral compounds, not many studied enzymes simultaneously possess broad substrate specificity and high enantio-selectivity. However, L-LDH was previously shown to be one of the efficient catalysts that should be useful in the enantio-selective reduction of unnatural-2- oxo acids [3].

Recent crystallin studies have revealed that one of the structural lens proteins, i.e. $\varepsilon$-crystallin isolated from the avian classes, appeared to be strusturally and functionally similar to heart-type lactate dehydrogenase, based on sequence comparison [4] and kinetic analysis $[5,6]$. This crystallin is especially rich in the lenses of birds belonging to the family, Anatidae, which includes ducks, swans and geese [7]. It comprised about 10-20\% of total protein in the duck lens and could be isolated easily by single-step purification [8]. Here we report the application of duck e-crystallin, an abundant natural mutant of LDH with high stability, for the synthesis of two chiral 2-hydroxy acids, (S)-2-hydroxybutanoic acid and (\$)-2-hydroxypentanoic acid [9]. By ulilizing the inexpensive and stable $\varepsilon$-crystallin with endogenous LDH activity, coupled with an in situ NADH regeneration system of formate/formate dehydrogenase, these

Correspondence address: S.-H. Chiou, Luboratory of Crystullin Research, Instilute of Biological Chemistry, Academia Sinica, PO Box 23-106, Taipei, Taiwan. pharmaceutically useful chiral compounds have been synthesized with high yields and high optical purity, thus circumventing the use of relatively expensive conventional LDHs or other organic synthesis approaches. This should prove a great potential in the asymmet. ic synthesis of some other biosynthetic intermediates.

\section{MATERIALS AND METHODS}

\subsection{Ensyme sources and reagenis}

The duck (a cross-bred hybrid between Cairina moschata and Ancs platyrhynchos var. domestica) lenses were obtained from the Taiwan Livestock Research linstitute, Yinan, Taiwan. NADH, 2-oxobutanoic acid and 2-oxopentunoie acid were obtained from Sigma Chemical Company (St. Louis, MO, USA). Formate dehydrogenase (FDH; from yeasi, EC 1.2.1.2.) was obtained in lyophilized form from Doehringer-Mannheim (Mannheim, Germany). Enzymes used for kinetic measurements were dissolver in $30 \mathrm{mM}$ phosphate-buffered solution. Chemieal shifts of ${ }^{\prime} \mathrm{H} N \mathrm{NMR}$ and ${ }^{13} \mathrm{C}$ NMR spectra were recorded with a Bruker AM-200 using solvent peaks as references. IR spectra were recorded from KBr thin films with a JASCO IR-700. UV absorbance was measured in a Hitachi U-2000 spectrophotometer. The optical rotation was measured using a Universal Polarimeter (Schmidt \& Haensch, Berlin, Germany). The HPI C system was composed of two Waters Model 6000 punps, a Waters MOdel 450 UV delector, and an M-660 solvent programmer. High purity solvents were obtained from A.LPS Chemical Company. Taiwain.

\subsection{Ensyme preparation}

The batch preparations of crystallins were routinely carried out from the pooled lenses of about 10 duck eyeballs. They were freshly collected from the above institute withou freezing, decapsulated, and homogenized in 20-30 ml of 0.05 $\mathrm{M}$ ammonium bicarbonate bufter, $\mathrm{pH} 7.7$, containing $5 \mathrm{mM}$ EDTA. The clear solution of the crude homogenate from centrifugation was lyophilized to give $200 \mathrm{mg}$ of the crude enzyme powder which was used directly without further purification. The purificution of ecrystallins from the crude extract was essentially according to the previous report on a TSK DEAE-650(M) anion-exchange column [5]. 


\subsection{Kinctics of E-crystallin}

The kintic parameters of e-crystallin were measured according to the previous report [3]. The L-laclate dehydrogenase aclivities of $\varepsilon$ crystallin were studied in the direction of reduction in the presence of NADH in $30 \mathrm{mM}$ phosphate buffer ( $\mathrm{pH} 7.2$ ) at $25^{\circ} \mathrm{C}$ by measuring the decrease in UV absorbance al $340 \mathrm{~nm}$. The assiny solution contain. ing NADH $(0.2 \mathrm{mM})$ and various concentrations of substrates plus various amounts of $\varepsilon$-crystallin was dissolved in $30 \mathrm{mM}$ phosphute buffer (pH 7.2) before use. The concentrations of substrates were increased from 0.2 to $5 K_{m}$, and the amount of e-crystallin was in. creased $t^{\prime}$ a factor of 100 -lold. The kinetic paramelers were obluined from Eadie-Hofstee plots.

\subsection{Stability of E-crusiallin}

The stubilities of E-crystallin under synthetic conditions were meas. ured spectrophotometrically by measuring the absorbance change al $340 \mathrm{~nm}$ due to NADH consumption in the LDH retstion. In a typical measurement, $\varepsilon$-crystallin $(0.56 \mathrm{mg})$ in phosphate buffer $(100 \mathrm{ml})$ was stirred at $35^{\circ} \mathrm{C}$ to maintain homogeneity. Periodically, $1.0 \mathrm{ml}$ aliguols were taken alut added to a cuvette containing NADH $(200 \mu \mathrm{M})$, pyruvate $(200 \mu \mathrm{M})$ in $0.2 \mathrm{M}$ phosphate buffer. The initial reaction rates were determined from time-depsendent plots of the decreasing absorbance at $340 \mathrm{~nm}$.

\subsection{Symhesis of (S)-2-ibulroxypentonole acid and (S)-2-1wylrowybu- lanuic acial}

To a solution of sodium formate $(1.7 \mathrm{~g}, 25 \mathrm{mmol})$, sodiun 2 oxopentanoate $(2.76 \mathrm{~g}, 20 \mathrm{mmol})$ and $\beta$-mercaploethanol $(100 \mu \mathrm{l})$ dissolved in water $(30 \mathrm{ml})$ was added $\operatorname{NAD}^{+}(66,0 \mathrm{mg}, 0.1 \mathrm{mmol})$. E-crystallin ( $80 \mathrm{U}$ ) and formale dehydrogenase (FDH, $8 \mathrm{U}$ ). The resulting solution was flushed with nitrogen for $30 \mathrm{~min}$. The $\mathrm{pH}$ of reaction solution was adjusted to 7,5 and kepl constant between 7,4 7.6 throughout the synthesis with a $\mathrm{pH}$-controller by adding $1.0 \mathrm{M}$ $\mathrm{HCl}$. Afler the reaction was complete (4.5 days), the solution was acidified to $\mathrm{pH} 2.0$ with $6 \mathrm{M} \mathrm{HCl}$ and extracted with dithyl ether (3 $\times 100 \mathrm{ml}$ ). The combined elher solution wis dried over anhydrous $\mathrm{Na}_{2} \mathrm{SO}_{4}$ and concentruted on a rotatory evaporator to give an oily residue which was solidified after further drying in vacuo. The yield was $2.19 \mathrm{~g}(18.4 \mathrm{mmol}, 93 \%)$. Using the same proced ure, from sodiun 2-oxobulanoate $(2,48 \mathrm{~g}, 20 \mathrm{mmol}), \beta$-mercaptoethanol $(0.1 \mathrm{ml})$. $\mathrm{NAD}^{+}$ (66 mg, $0 . i \mathrm{mmoi})$, E-crystallin $(80 \mathrm{U})$, sodium formale $(1.7 \mathrm{~g} .25$ mmol) and FDH $(\& U)$, (S)-2-hydroxybutanoic acid $(1.93 \mathrm{gg}, 18.4$ numol, 92\%) was votained. The physicochemical and spectroscopic datid are shown as follows:

(S)-2.inctroxwbutaraic actl: $\mathrm{mp} 49-50^{\circ} \mathrm{C}$ (Lit. $\mathrm{mp} 54.5-55.5^{\circ} \mathrm{C}$ in $[3]):[\alpha]_{1}^{24}=+6.4\left(\mathrm{c} 2.03 \%, \mathrm{CHCl}_{3}\right)\left(\mathrm{Lit},[\alpha]_{13}^{3 / 3}=+6.4\left(\mathrm{c} 2.63 \%, \mathrm{CHCL}_{3}\right)\right.$ in [10]): 'H NMR (CDCl, $200 \mathrm{MHz}$ ), $\delta: 6.54$ (br s. $2 \mathrm{OH}$ ), 4.24 (dd. $\left.\mathrm{J} \equiv 7 \mathrm{~Hz}, \mathrm{~J}^{\prime}=4 \mathrm{~Hz}, 1 \mathrm{H}\right), . .88(\mathrm{~m}, 1 \mathrm{H}), 1.76(\mathrm{~m}, 1 \mathrm{H}), 1.00\left(\mathrm{t}_{1} \mathrm{~J}=\right.$ $7 \mathrm{~Hz}, 3 \mathrm{H}) \mathrm{ppm} ;{ }^{13} \mathrm{C}$ NMR $\left.(\mathrm{CDCl})_{3}\right), \delta: 179.5,71.2,27.2,8.9 \mathrm{ppm}$ : IR(KBr), 1128, 1217, 1723, 2971, 3410, 2500-3700 $\mathrm{cm}^{-1}$.

(S)-2-hydroxypentanole acidl: mp $53-55^{\circ} \mathrm{C}$ (Lil, mp 52-55 $5^{\circ} \mathrm{C}$ in [10]): $[\alpha]^{25}=-2.69\left(\mathrm{c} 4.8 \%, \mathrm{H}_{2} \mathrm{O}\right)\left(\right.$ Lit. $[\alpha]^{2.5}=-2.7\left(\mathrm{c} l-5 \%, \mathrm{H}_{2} \mathrm{O}\right)$ in [ll]); ${ }^{1} \mathrm{H}$ NMR $\left(\mathrm{CDCl}_{3}, 200 \mathrm{MHz}\right), 8: 6.7 \mathrm{c}(\mathrm{br}, 2 \mathrm{H}), 4.26(\mathrm{~d}, \mathrm{~d}, 1 \mathrm{H}), 1.78$ $(\mathrm{m}, 1 \mathrm{H}), 1.67(\mathrm{~m}, 1 \mathrm{H}), 1.46(\mathrm{~m}, 2 \mathrm{H}) 0.93(1,3 \mathrm{H}) \mathrm{ppm},{ }^{13} \mathrm{C}$ NMR $\left.\left(\mathrm{CDCl}_{3}\right) \delta: 179.8,70.1,36.1,18.0,13.6 \mathrm{pl}\right) \mathrm{m} ; \mathrm{IR}(\mathrm{KBr}) 1132,1222$. $1723,2960,3410,2400-3800 \mathrm{~cm}^{-1}$.

The pharmaceutical use of these two chiral compounds as inlermediates in the synthesis of vurious inseel pheromones and fungicides hats been mentioned $([3,9,10]$ and references ciled therein).

\section{RESULTS}

$\varepsilon$-Crystallin, a relatively abundant lens protein present in some avian and rentilian species, was shown to possess an i"lactate dehydrogenase activity with high stability suitable for application to enzyme technology [5]. Lactate dehydrogenase is a 'house-keeping' nicoti-

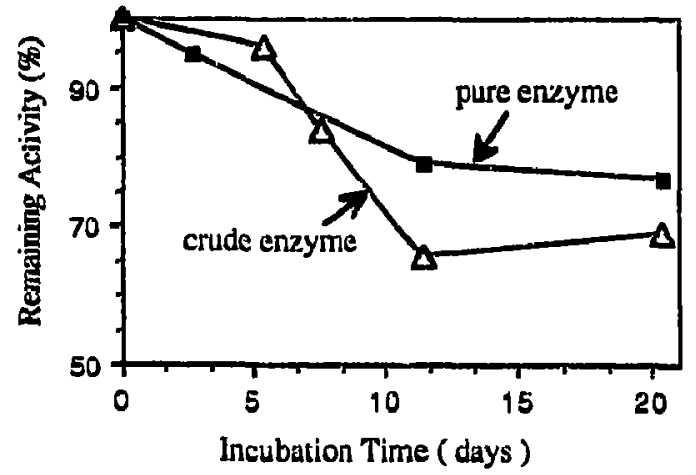

Fig. 1. Stability of duck crude extract and purifed e-crystallin in aqueous solution at $\mathrm{pH} 7.5$ and $25^{\circ} \mathrm{C}$. $\varepsilon$-Crystallin $(0.56 \mathrm{mg})$ and erude homogentte (1.0 mg) each in phosphate bulfer (100 ml) were stirred at $35^{\circ} \mathrm{C}$ to mainiain homogeneity. Periodically, $1.0 \mathrm{ml}$ aliquols were tulics and udded to a cuvelte containing NADH (200 $\mu \mathrm{M})$, pyruvate $(200 \mu \mathrm{M})$ in $0.2 \mathrm{M}$ phosphite buffer, $\mathrm{pH} 7 . \therefore$ The slabilities were studied spectrophotometrically by medsuring initial retetion rates as reflected in the absorbance change at $340 \mathrm{um}$ due to NADH consumption in the $\mathrm{LDH}$ reaction at $25^{\circ} \mathrm{C}$.

namide-dependent enzyme of glycolysis, the major metabolic pathway that metabolizes glucose to lactate and generares the energy in the form of ATP in the absence of oxygen for most organisms [12]. The presence of the specific distribution of different LDH isozymes in various tissues does not seem to be a random occurzence but is of functional importance in tissue metabolism and has developed [rom natural selection [13]. Many methods for L.LDH immobilization have been documented to improve the stability of L-LDH for chiral synthetic pulpose $[14,15]$. A convenient in situ NADH regeneration system for the $\mathrm{LDH}$ reduction reaction has also been developed to enhance the capability of LDHs for preparative scale synthesis [16]. We report here the first successful application duck e-crystallin with L-LDH activily as a catalyst for chiral 2-hydroxy acid synthesis.

$\varepsilon$-Crystallin was prepared from the pooled lenses of eyeballs ( 10 balls, $900 \mathrm{mg}$ ), homogenized and centrifuged to give a crude lyophilized enzyme preparation $(200 \mathrm{mg})$ which has a specific activity of about 100-120 $\mathrm{U}$ foi reduction of pyruvate. Further purification by a DEAE ion-exchange chromatography gave a specific activity of $610 \mathrm{U}$. Therefore isolation and purification of $\varepsilon$-crystallin was very easy as compared to the convenlional purification of various LDHs from other tissues [17]. The structures of these products were confirmed by ${ }^{1} \mathrm{H} N M R,{ }^{13} \mathrm{C}$ NMR, IR and optical rotation data. They were obtained in high yields (92 and 93\%) and optical purity ( $>99 \%$ for both products). From an HPLC analysis of the reaction product in each time interval, more than $90 \%$ of the product was formed in the first half of the total reaction period. In this study the L-lactate dehydrogenase activity associated with the $\varepsilon$-erystallin of duck lens is found to be very stable $\left(l_{1 / 2}\right.$ at $\mathrm{pH} 7.5$ and 


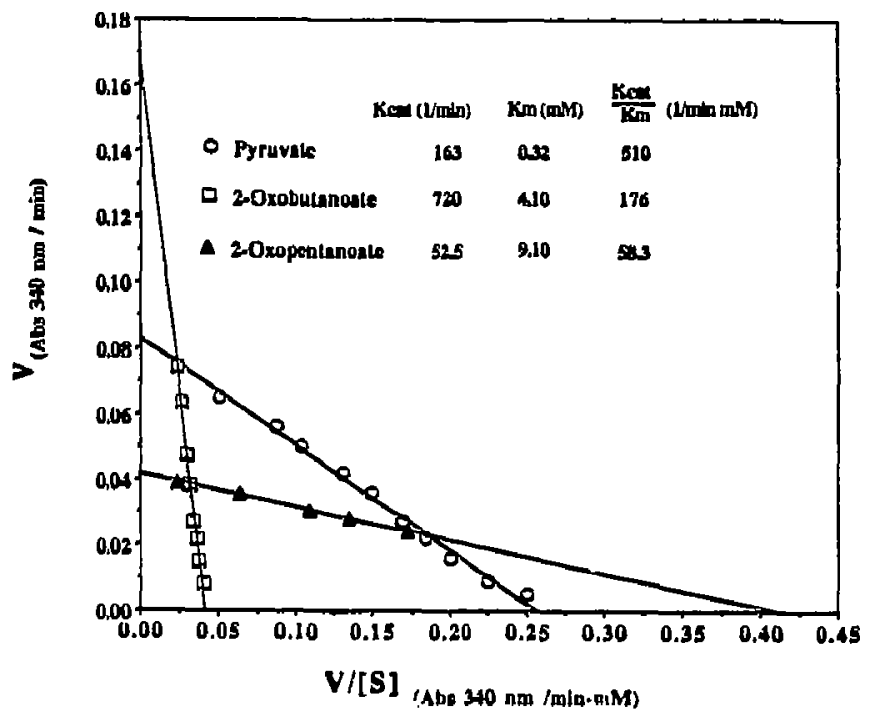

Fig. 2. Deternimation of kinetic parameters by Eadie-Hofstee plots for the reduction of three 2-oxo acids culalyzed by purified duck $\varepsilon$-crystallin. The L-lactate dehydrogenase activities of $\varepsilon$-crystallin were studied in the direstion of reduction in the presence of NADH in 30 $\mathrm{mM}$ phosphate buffer (pH 7.2) at $25^{\circ} \mathrm{C}$ by measuring the decrease in UV absorbance at $340 \mathrm{~mm}$. The assay solution conlaining NADH $(0.2$ $\mathrm{mM}$ ) and various concentrations ol substrales was dissolved in $30 \mathrm{mM}$ phosphale buffer ( $\mathrm{pH} 7.2$ ) before use. The concentrations of substrates were increased from 0.2 to $5 K_{\text {mit }}^{\prime}$ and the amount of $\varepsilon$-crystallin was increased by a liuclor of 100-fold.

room temperature is more than twenty days and about $4 \mathrm{~h}$ at $62^{\circ} \mathrm{C}$ ).

Fig. 1 shows the stability of crude and purified $\varepsilon$ crystallin in phosphate buffer $(\mathrm{pH} 7.5)$ at $25^{\circ} \mathrm{C}$. The activity of an aliquot of the reaction mixture $30 \mathrm{~s}$ after addition of the $\varepsilon$-crystallin solution was taken as $100 \%$ activity. The rate of inactivation of the enzyme was measured on the basis of the remaining activity (using the activity of $30 \mathrm{~s}$ incubation of $\varepsilon$-crystallin as the reference activity of $100 \%$ ). The enzyme can maintain its activity in both phosphate buffer and in pure water. The latter condition is mole suitable for large-scale synthesis because the mixture of enzymes, coenzyme, and substrates in solution can serve as a buffer. As shown in Fig. 1, aftel a 21-day incubation, both crude and purified enzyme still possessed at least $65 \%$ of their original activity. Fig. 2 shows the kinetic parameters of $\varepsilon$-crystallin for the LDH-catalyzed reduction of pyruvate, 2-oxobutanoate, and 2-oxopentanoate. The enzyme has a specific activity of $610 \mathrm{U} / \mathrm{mg}$ and $k_{\text {sut }}$ of 720 $\mathrm{min}^{-1}$ and $53.5 \mathrm{~min}^{-1}$ for $(S)$-2-butanoic acid and $(S)$-2pentanoic acid, respectively. The $k_{\text {cut }}$ value of 2-oxobutanoate is 14-fold higher than that of 2-oxopentanoate.

\section{DISCUSSION}

Most of 1.-LDHs used for synthetic application must possess a high specific activity and fair stability

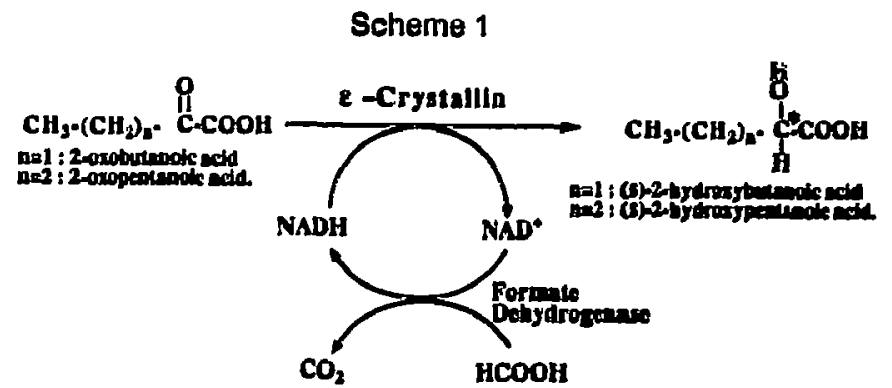

Scheme 1. $\varepsilon$-Crystallin-eatalyzed synthesis of (S)-2-hydroxy acids by an in situ NADI regencration system coupled with formate/fermate dehydrogenase.

$[3,10,18,19]$. As shown in the previous report $[5,6]$ regarding the stability and specific activity shown here $\varepsilon$-crystallin actually exhibited better stability and higher specific activity than the commercial LDHs isolated from different tissues of various animal species [3]. Comparison of kinetic data for \&-crystallin with those of other known LDHs used previously in asymmetric synthesis also reveals that the $\varepsilon$-crystallin has a higher $k_{\text {sua }}$ than the catalytic constants of all the others $[3,18]$.

Scheme 1 shows the overall reactions for the generation of 2-hydroxy acids utilizing the L-LDH catalyzed reactions in coupling with a formate/formate dehydrogenase system. The rate limitation is dependent on the activity of formate dehydrogenase, i.e. increasing the amount of formate dehydrogenase can shorten the time for reaction completion. Similar results are obtained when using the same units of purified $\varepsilon$-crystallin or crude crystallin extract as catalyst.

In summary, the procedure illustrated here describes the practical application of $\varepsilon$-crystallin in the preparative-scale enzymatic synthesis of optically pure 2-hydroxy acids. Since the $\varepsilon$-erystallin is a naturally abundant structural protein (10-20\% of total lens protein) present in some avian lenses it could prove to be more economical than adopting conventional LDHs from heart or muscle tissues, which usually are present in much lower quantity. In addition the kinetic parameters shown for duck e-crystallin are also superior to those of conventional LDHs regarding the crucial catalytic properties for biosynthetic purposes.

Ackmowledgements: This work was supported in part by Academia Sinica and the National Science Council, Taipei, Taiwan. Thanks are also due to the kind provision of duck lenses by the Taiwan Livestock Research Institute.

\section{REFERENCES}

[1] Whitesides, G.M. and Wong, C.-H. (1985) Angew. Chem., liat. Ed. Engl. 24, 617-638.

[2] Jones, J. B. (1986) Tetrahedron 42. 3351-3403.

[3] Kim, M.-J. and Whitesides, G.M. (1988) J. Am. Chem. Sur. 110, 2959-2964. 
[4] Wistow, G.J., Mulders, J.W.M. and de Jong, W.W. (1987) Nature 320, 622-624.

[5] Chiou, 5.-H., Lee, H.-J. and Chang, G.-G. (1990) Biochem. J. 267, 51-58.

[6] Chang, G.-G., Huang, S.-M, and Chiou, S.-H. (1991) Arch. Biochem. Biophys. 284, 285-291.

[7] Chiou, S.-H., Chang, W.-P. and Lai, T.-A. (1989) Curr. Eye. Res. 8, 1055-1061.

[8] Chiou, S.·H. and Chang, W.-P. (1989) In: Internutional Symposium on Biologically Active Proteins and Peptides (S.-H. Chiou, K.-T. Wang and S.-H. Wu, eds.) pp. 81-89, Academia Sinica, Taipei, Taiwan.

[9] Ramos Tombo, G.M. and Bellus, D. (1991) Angew, Chem, Int. Ed. Engl. 30, 1193-1215.

[10] Bur, D., Luylen, M.A., Wynn, H., Provencher, L.R., Jones, J. B., Gold, M.. Fresen, J.D., Clarke, A.R. and Holbrook, J.J. (1989) Can. J. Chen. 67, 1065-1070.

[11] Wintitz, M., Blocli-Frankenthal, L., Izumiya, N., Birnbaum. S.M., Baker. C.G. and Greenstein. J,P. (1956) J. Am. Chem. Soc. 78, 2423-2427.
[12] Metzler, D.E. (1977) Biochemistry: The Chemieal Reactions of Living Cells, Academic Press, New York.

[13] Cahn, R,D., Kaplan, N.O., Levine, L. and Zwilling, E. (1962) Science 136, 962-969.

[14] Dixon, J.E. and Stolzenbach, F.E. (1973) Biochem. Biophys. Res. Commun. 52, 905-912.

[15] Siegbahn, N., Mansson, M.O. and Mosback, K. (1987) Method Enzymol, 136, 103-113.

[16] Shaked, Z. and Whitesides, G.M. (1980) J. Am, Chem. Soc. 102, 7105-7107.

[17] Pesce, A., McKay, R.H., Stolzenbach, F., Calın, R.D. and Kaplan, N.O. (1964) J. Biol. Chem. 239, 1753-1761.

[18] Luyten, M.A., Bur, D., Wynn, H., Partis, W., Gold, M., Friesen, J.D. and Jones, J.B. (1989) J. Am. Chem. Soc. 111, 6800-6804.

[19] Demchenko, A.P., Rusyn, O.l. and Saburova, E.A. (1989) Biochim. Blophys. Acta 998, 196-203. 